\title{
Pengolahan Limbah Kulit Durian dan Baterai Bekas Menjadi Salah Satu Sumber Energi Listrik yang Ramah Lingkungan
}

\author{
Nelmi Agustina ${ }^{1, \dagger}$, Muhammad Gifron ${ }^{1}$, Doris Wela ${ }^{1}$ \\ ${ }^{1}$ Institut Agama Islam Negeri (IAIN) Batusangkar \\ †corresponding author: nelmiagustina067@gmail.com
}

\begin{abstract}
Abstrak. Seiring dengan bertambahnya jumlah penduduk dunia, selalu diiringi oleh masalah limbah yang berasal dari sampah, baik sampah organik maupun non organik. Berbagai usaha untuk mengatasi masalah limbah tersebut secara berkesinambungan terus dilakukan, baik itu sampah-sampah anorganik seperti, berbahan plastik, karet dan lain-lain. Bisa dimanfaatkan kembali melalui daur ulang menjadi barang-barang kebutuhan harian. Sedangkan untuk sampah organik selain dimanfaatkan untuk pupuk, juga dapat digunakan sebagai bahan dasar pengisi baterai untuk menghasilkan energi alternatif yang ramah lingkungan. Terkhususnya untuk pemanfaatan limbah organik dalam pembuatan baterai telah dilakukan dengan beda potensial tertinggi yang dihasilkan adalah 1,67 volt. Dalam penelitian ini dilakukan modifikasi massa bahan pengisi baterai yang bersumber dari kulit durian yang yang diproses khususnya melalui pengeringan menggunakan oven serta dicampur dengan asam dan ada juga kulit durian yang dijemur selama 7 hari dengan massa kulit durian 3, 5, dan 10. Beda potensial baterai tertinggi yang didapatkan adalah 10 gram yaitu sebesar 1,67 volt. Selanjutnya baterai dengan massa 10 gram difabrikasi dalam jumlah tertentu yang digunakan untuk menyalakan LED. Baterai tersebut dirangkai baik secara seri maupun paralel untuk menghasilkan beda potensial yang bervariasi.
\end{abstract}

Kata Kunci: Baterai ekas, Energy listrik, Kuat arus, Limbah kulit durian, Tegangan.

Abstract. Along with the growing number of the world populations, there always followed by troubles waste derived from trash, organic waste, and non-organic waste. Many attempts to deal with an organic waste such as plastic waste, rubber, and etc, has been continued, so those waste can be recycled and reused for daily demand. On the other hand, organic waste can be used as fertilizer, and basic material for the battery that results an environmental friendly alternative energy. Especially to utilize the organic waste, the making of battery has been done that yields highest voltage, 1.67 volts. This research aims to modify the mass filler of the battery that obtained from durian skin which is processed by mixing it with acid and drying it using oven, there also other technique by drying the durian skin under the sun for about 7 days which varied masses of $3 \mathrm{gram}, 5 \mathrm{gram}$, and $10 \mathrm{gram}$. The highest voltage that obtained is 1.67 volt using 10 gram durian skin. Further, the battery with 10 grams durian skin is then fabricated in a specified number to light up the LED. This battery placed either in serial or parallel circuit to obtain varied voltage.

Keywords: Disused battery, Durian skin waste, Electrical current, Electrical energy, Voltage.

\section{PENDAHULUAN}

Energi menjadi komponen penting bagi keberlangsungan hidup manusia karena hampir semua aktifitas kehidupan manusia sangat tergantung pada ketersedian energi yang cukup. Kebutuhan akan energi semakin bertambah sejalan dengan perkembangan teknologi dan pertambahan penduduk teknologi. Kebutuhan energi yang selama ini berasal dari bahan bakar fosil tidak bisa diharapkan uantuk waktu yang sangat lama. Apabila tidak digunakan energi alternatif selain bahan bakar fosil berupa batu bara dan minyak bumi maka minyak bumi diperkirakan akan habis dalam waktu kurang dari 10 tahun, sedangkan gas bumi sekitar 30 tahun, dan batubara akan habis sekitar 50 tahun. Oleh sebab itu, diperlukan sumber energi alternatif baru yang dapat memenuhi kebutuhan atau paling tidak dapat menghemat penggunaan energi dari bahan bakar fosil tersebut. Energi alternatif tersebut diharapkan memiliki sifat energi yang ramah lingkungan dan merupakan energi yang dapat diperbaharui melalui pemanfaatan limbah organik seperti sayur-sayuran dan buah-buahan. Limbah tersebut menjadi sasaran pemanfaatan energi alternatif dikarenakan sumber 
energi listrik yang berasal dari batu bara dan minyak bumi, tidak ramah lingkungan, karena menimbulkan polusi udara dan untuk memperbaharuinya memerlukan waktu yang lama. Energi listrik yang berasal dari energi terbarukan terus dikembangkan.

Ilmu pengetahuan mengenai kelistrikan berkembang pesat pada abad 19. Berawal dari penemuan baterai oleh Alessandro Volta, selanjutnya sampai akhirnya penemuan bola lampu (lightbulb) listrik pertama oleh Thomas Alfa Edison. Lempengan filamen dengan suhu yang tinggi dengan akhirnya bercahaya merupakan proses yang terjadi pada bola pijar. Pemanasan ini bersumber dari baterai atau sumber listrik lain sebagai sumber energi yang akan memanaskan filamen bola lampu.

Baterai adalah menjadi sumber energi dan merupakan suatu alat yang dapat menghasilkan energi listrik dengan melibatkan transfer elektron melalui suatu media yang bersifat konduktif dari dua elektroda (anoda dan katoda) sehingga menghasilkan arus listrik dan beda tegangan. Namun jika energi dari baterai tersebut sudah habis, maka baterai tersebut bisa menjadi polusi dan mencemarkan lingkungan karena baterai termasuk limbah non-organik, sehingga tidak bisa diuraikan. Limbah baterai yang ada merupakan limbah B3 (Bahan Beracun dan Berbahaya). Jika limbah tersebut tidak bisa diiolah kembali dengan baik maka akan menyebabkan kerusakan lingkungan.

Dari permasalahan di atas, maka penulis mempunyai gagasan untuk melakukan penelitian dengan memanfaatkan barang bekas dan limbah organik sebagai sumber energi alternatif. Penelitian inimenggunakan barang bekas yang digunakan adalah baterai dengan mengganti isi dari baterai tersebut dan memanfaatkan sampah dari kulit durian dan asam yang telah busuk yang tidak digunakan lagi, yang nantinya diharapkan dapat memperoleh energi alternatif yang ramah lingkungan. Harapan penelitian ini adalah dapat menjadi solusi alternatif dari energi terbarukan yang berasal dari limbah baterai dan limbah organik yang berasal dari kulit durian agar semua orang khususnya pada masyarakat yang terpencil yang masih belum dialiri arus listrik dan masyarakat dari ekonomi menengah ke bawah. Sebelumnya sudah dilakukan penelitian terdahulu oleh Muhlisin, dkk tahun 2015 dan Khairiah tahun 2017, yang mana kedua peneliti memanfaatkan pasta elektrolit kulit durian sebagai bio baterai. Sedangkan penulis disini memanfaatkan kulit bagian dalam durian yang dihaluskan menggunakan belender yang dicampur dengan asam yang telah busuk, kemudian dikeringkan menggunakan oven selama 2 jam dan kulit durian lainnya dijemur dengan paparan sinar matahari langsung selama 7 hari.

\section{METODE PENELITIAN}

\section{Jenis Penelitian}

Dalam penelitian ini, penulis menggunakan jenis metode penelitian dan pengembangan (Research and Development). Menurut Sugiyono (2013:4),"Metode penelitian dan pengembangan merupakan metode penelitian yang digunakan untuk menghasilkan produk tertentu dan menguji keefektifan produk tersebut". Penelitian ini bertujuan untuk meneliti dan mengembangkan limbah kulit durian dan barang bekas yaitu baterai menjadi energi listrik yang ramah lingkungan melalui langkah-langkah yang sistematis kemudian di uji kelayakan dari segi produk dan penggunaan serta keberlanjutannya di masa mendatang.

\section{Tempat dan Waktu Penelitian}

Penelitian ini dilaksanakan di Laboratorium Fisika Dasar, tepatnya pada L.I.7 IAIN Batusangkar pada tanggal 1 Januari 2018 - 15 Januari 2018.

\section{Alat dan Bahan}

Alat dan Bahan digunakan pada penelitian ini sebagai berikut : 
1. Kabel penghubung (jepit buaya) sebagai penghubung rangkaian.

2. Baterai $\mathrm{ABC}$ ukuran 1.5 volt 2 buah dan 3 volt 2 buah

3. LED sebagai pengukur kemampuan daya menghidupkan lampu led.

4. Gelas kimia, oven

5. Pisau dan Obeng

6. Limbah organik yaitu kulit durian

7. Blender sebagai alat penghalus kulit durian

8. Voltmeter

9. Asam yang telah busuk yang tidak bisa digunakan lagi

10. Multimeter Digital

\section{Prosedur Penelitian}

Langkah kerja penelitian sebagai berikut :

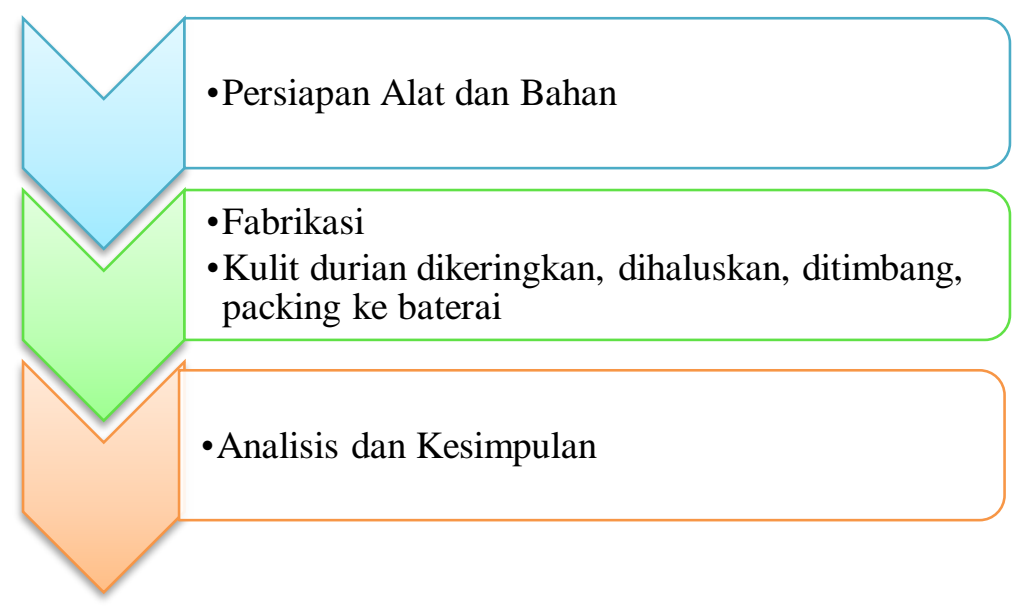

Tahap persiapan alat dan bahan dalam pembuatan alat ini, penulis mempersiapkan alat dan bahan yang digunakan untuk menunjang pembuatan alat ini, persiapan yang dilakukan penulis adalah sebagai berikut:

1. Menggambil limbah kulit durian, kemudian kulit durian tersebut ada yang dikeringkan menggunakan oven selama 2 jam dan ada juga kulit durian yang lain dijemur selama 1 minggu.

2. Kulit durian yang telah dikeringkan menggunakan oven dan kulit durian yang dijemur dengan paparan sinar matahari secara langsung dipisahkan kulit bagian dalam dan bagian luarnya mengggunakan pisau.

3. Kulit durian yang bagian dalam tadi kita haluskan menggunakan belender, yang satu dicampur dengan asam dan yang lain tanpa campuran asam.

4. Mengambil baterai $\mathrm{ABC} 1,5$ volt dan 3 volt, kemudian keluarkan mangan oksidasi yang ada didalam baterai tersebut menggunakan obeng.

5. Mengganti isi dari baterai yang telah dikeluarkan tadi dengan kulit durian yang telah dihaluskan, sebelum kita masukan isi kulit durian ke dalam tabung baterai, terlebih dahulu kita timbang massa dari kulit durian yang telah dihaluskan.

6. Menghubungkan baterai dengan kabel penghubung.

7. Mengamati dan melakukan pengukuran tegangan dan kuat arus dari baterai yang telah di isi dengan kulit durian yang telah dihaluskan yang diberkan asam dan tanpa asam.

8. Menghubungkan dengan lampu LED, dan amati apa yang terjadi pada lampu LED tersebut dan bagaimana hasilnya antara baterai yang berisi kulit durian yang dicampur asam dan tanpa asam. 
Fabrikasi ketika kita melakukan tahap persiapan, kemudian kita amati alat yang telah kita buat tadi, kemudian kita lihat rangkaian dari baterai dan lampu menggunakan kabel penghubung tadi apakah rangkaiannya benar, jika rangkaiannya telah benar kemudian kita lakukan pengukuran tegangan dan kuat arus menggunakan multimeter digital, setelah itu kita bandingkan hasil yang kita dapatkan menggunakan baterai yang isinya kita ganti dengan kulit durian yang dicampur dengan asam dan tanpa asam serta dengan baterai yang aslinya atau baterai yang berisi mangan oksidasi. Setelah itu kita kumpulkan data yang telah kita dapatkan, kemudian kita masukkan ke dalam tabel hasil pengamatan.

TABEL 1. Tabel Data Pengamatan 1,5 Volt dari Kulit Durian dengan Tegangan diukur 1,638 volt.

\begin{tabular}{cccc}
\hline Massa Kulit Durian & Massa Baterai Kecil & Tegangan & Arus \\
\hline 3 gram & 13 gram & 1,2 volt & $0,08 \mathrm{~A}$ \\
5 gram & 14 gram & 1,59 volt & $0,09 \mathrm{~A}$ \\
10 gram & 15 gram & 1,67 volt & $0,11 \mathrm{~A}$ \\
\hline
\end{tabular}

TABEL 2. Tabel Pengamatan Batterai Limbah Kulit Durian (tanpa di oven)

\begin{tabular}{lccc}
\hline Massa Kulit Durian & Massa Baterai Kecil & Tegangan & Arus \\
\hline 3 gram & 13 gram & 1,2 volt & $0,08 \mathrm{~A}$ \\
5 gram & 14 gram & 1,59 volt & $0,08 \mathrm{~A}$ \\
10 gram & 15 gram & 1,67 volt & $0,08 \mathrm{~A}$ \\
\hline
\end{tabular}

TABEL 3. Tabel Pengamatan Batterai Limbah Kulit Durian (dengan oven)

\begin{tabular}{cccc}
\hline Massa Kulit Durian & Massa Baterai Kecil & Tegangan & Arus \\
\hline 10 gram & 15 gram & 1,4 volt & $0,08 \mathrm{~A}$ \\
\hline
\end{tabular}

Analisis dan kesimpulan dari pengamatan di atas, diperoleh hasil tegangan antara baterai yang pastanya berisi kulit durian dijemur selama 7 hari dengan baterai yang pastanya di oven selama 2 jam dan dicampur dengan asam yang telah busuk didapatkan nilai tegangannya tidak terlalu jauh. Dari pengamatan yang dilakukan baterai yang berisi pasta kulit durian yang dijemur selama satu minggu hanya bisa bertahan dalam 10 hari. Sedangkan baterai pastanya yang berisi kulit durian yang di oven selama 2 jam dan dicampur dengan asam yang telah busuk daya tahannya 25 hari masih nyala, dapat di ambil kesimpulan bahwa baterai yang pastanya berisi kulit durian yang dicampur dengan asam serta untuk pengeringannya menggunakan oven selama 2 jam lebih baik dan daya tahannya lebih lama. Dan untuk waktunya lebih singkat dibandingkan dengan yang dijemur dengan paparan sinar matahari secara langsung, maka kita dapat menghasilkan baterai banyak dalam jangka waktu hanya 2,5 jam saja yaitu baterai yang ramah lingkungan.

\section{HASIL DAN PEMBAHASAN}

\section{Hasil Penelitian}

Merancang sebuah alat yang ramah lingkungan untuk menggantikan bahan bakar fosil yang semakin menipis, disini penulis mempunyai gagasan atau ide yaitu membuat sebuah alat sederhana menggunakan barang bekas dan limbah organik yang bisa mencemari lingkungan, penulis menggunakan baterai dan limbah kulit durian serta asam yang telah busuk yang nantinya bisa menghasilkan energi listrik yang ramah lingkungan dan bisa kita gunakan untuk menggantikan 
energi yang tak terbarukan dari bahan bakar fosil yang diperkirakan akan habis beberapa tahun kedepan dan untuk itu kita membuat sebuah alat alternatif yang bisa kita temukan dan mudah untuk kita buat, khususnya untuk daerah yang belum masuk listrik dan masyarakat yang ekonomi menegah ke bawah.

Dari pengamatan di atas, diperoleh hasil tegangan antara baterai yang pastanya berisi kulit durian dijemur selama 7 hari dengan baterai yang pastanya di oven selama 2 jam dan dicampur dengan asam yang telah busuk didapatkan nilai tegangannya tidak terlalu jauh. Dari pengamatan yang dilakukan baterai yang berisi pasta kulit durian yang dijemur selama satu minggu hanya bisa bertahan dalam 10 hari. Sedangkan baterai pastanya yang berisi kulit durian yang di oven selama 2 jam dan dicampur dengan asam yang telah busuk daya tahannya 25 hari masih nyala, dapat di ambil kesimpulan bahwa baterai yang pastanya berisi kulit durian yang dicampur dengan asam serta untuk pengeringannya menggunakan oven selama 2 jam lebih baik dan daya tahannya lebih lama. Dan untuk waktunya lebih singkat dibandingkan dengan yang dijemur dengan paparan sinar matahari secara langsung, maka kita dapat menghasilkan baterai banyak dalam jangka waktu hanya 2,5 jam saja yaitu baterai yang ramah lingkungan.
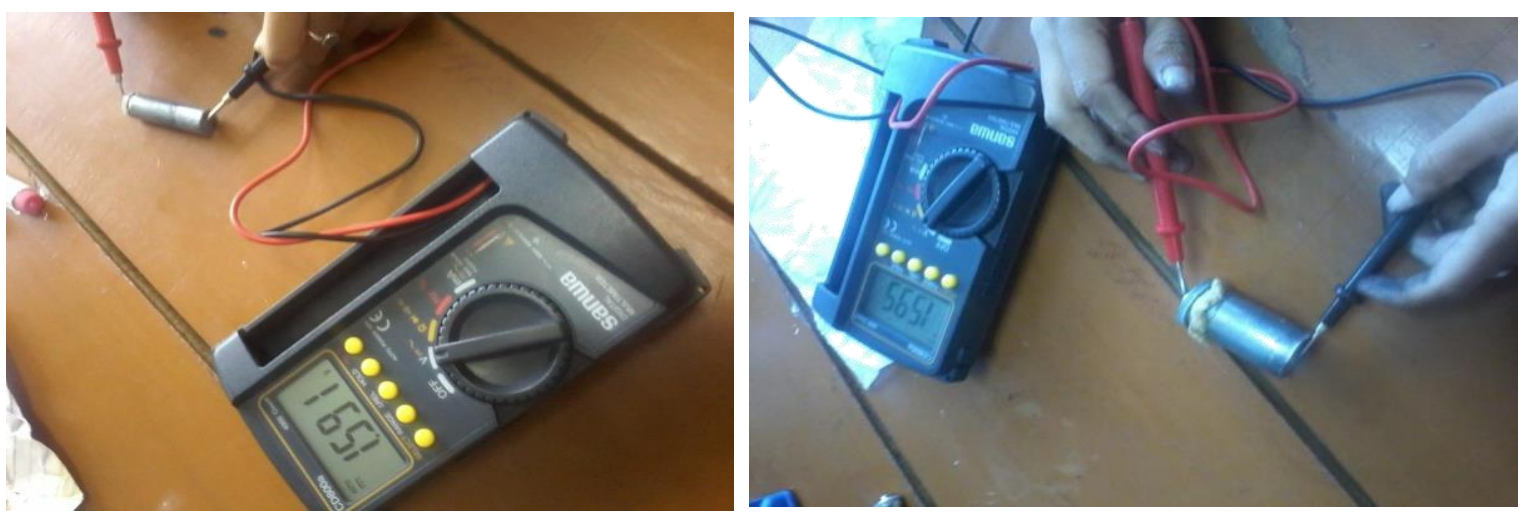

GAMBAR 1. Mengukur tegangan, arus, tahanan pada batterai menggunakan multimeter digital.
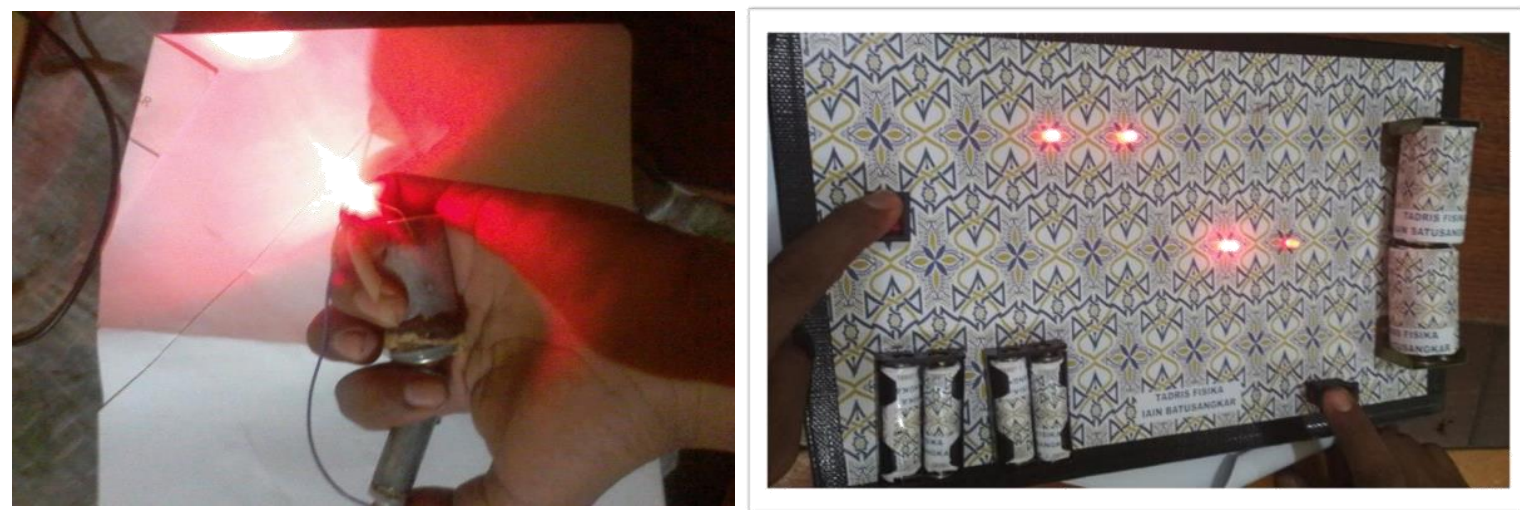

GAMBAR 2. Menyalakan led menggunakan batterai dari limbah durian.

\section{KESIMPULAN}

Setelah melakukan penelitian dapat disimpulkan dari percobaan yang telah dilakukan, bahwa kulit durian dapat menggantikan mangan oksidasi atau elektrolit pada baterai bekas, sehingga baterai bekas dapat digunakan kembali dan diperoleh hasil tegangan antara baterai yang pastanya berisi kulit durian dijemur selama 7 hari dengan baterai yang pastanya di oven selama 2 jam dan dicampur dengan asam yang telah busuk didapatkan nilai tegangannya tidak terlalu jauh. Dari pengamatan yang dilakukan baterai yang berisi pasta kulit durian yang dijemur selama satu minggu hanya bisa bertahan dalam 10 hari. Sedangkan baterai pastanya yang berisi kulit durian 
yang di oven selama 2 jam dan dicampur dengan asam yang telah busuk daya tahannya 25 hari masih nyala, dapat di ambil kesimpulan bahwa baterai yang pastanya berisi kulit durian yang dicampur dengan asam serta untuk pengeringannya menggunakan oven selama 2 jam lebih baik dan daya tahannya lebih lama. Dan untuk waktunya lebih singkat dibandingkan dengan yang dijemur dengan paparan sinar matahari secara langsung, maka kita dapat menghasilkan baterai banyak dalam jangka waktu hanya 2,5 jam saja yaitu baterai yang ramah lingkungan.

\section{UCAPAN TERIMAKASIH}

Penulis mengucapkan rasa terimakasih yang sebesar - besarnya kepada Ayah anda Dr. Marjoni Imamora, M.Sc dan Ibunda Artha Nesa Chandra, M.Pd dan Venny Haris M.Si yang telah membimbing penulis dan terimakasih juga atas Keluarga yang telah memberikan dukungan beserta doa sehingga karya tulis ini dapat terselesaikan oleh penulis.

\section{REFERENSI}

[1] S. Handayani, dkk, Fisika 1: Untuk SMA/MA Kelas X (Jakarta, Pusat Perbukuan, Departemen Pendidikan Nasional, 2009)

[2] Khairiah dan Destini, R. Analisis Kelistrikan Pasta Elektrolit Limbah Kulit Durian (Durio Zibethinus) Sebagai Bio Baterai. Prosiding Seminar Nasional Pendidikan UNTIRTA hal 41 - 44.

[3] M. Muhlisin, N. Soedjarwanto, M. Komarudin, Pemanfaatan Sampah Kulit Pisang dan Kulit Durian Sebagai Bahan Alternatif Pengganti Pasta Batu Baterai. Electrician-Jurnal Rekayasa dan Teknologi Elektro Volume 9 No3 September 2015.

[4] S. Nurachmandani, Fisika 1 : Untuk SMA/MA Kelas X (Jakarta, Pusat Perbukuan, Departemen Pendidikan Nasional, 2009)

[5] Sugiyono. Metode Penelitian Kuatitatif, Kualitatif dan R \& D (Bandung, ALFABETA, cv, 2013)

[6] J. Sumarsono, Fisika : Untuk SMA/MA Kelas X (Jakarta, Pusat Perbukuan, Departemen Pendidikan Nasional, 2009) 